\title{
Indonesian National Culture in Supporting the Implementation of Carbon Economy
}

\author{
Sulastini \\ Kalimantan Islamic University \\ Muhammad Al-Banjari Arsyad \\ Banjarmasin, Indonesia
}

\begin{abstract}
Since forests have increasingly been considered a critical issue under United Nations Framework Convention for Climate Change, a new economic approach to mitigating terrestrial emissions associated with climate change called 'REDD+' (Reducing Emissions from Deforestation and forest Degradation) is introduced. REDD+ which is later known as carbon economy is a proposed performance-based mechanism in which developed country donors, corporations, non-governmental organizations, and individuals will compensate developing countries for forest emissions reductions. Southeast Asia hosts a number of early REDD+ type projects. However, there have been distinctive differences between countries that have been successful in implementing REDD+. Portraying on frameworks of national culture, this article is exploring the applicability of carbon economy in the developing country of Indonesia which has been located the most REDD+ projects.
\end{abstract}

Keywords: REDD+, carbon economy, national culture, Indonesia.

\section{INTRODUCTION}

Southeast Asia hosts a number of early REDD+ type projects (as of January 2012): Indonesia (44 projects), Cambodia (4 projects), Malaysia (1 project), Vietnam (7 projects), Thailand (1 project), Papua New Guinea (6 projects), Philippines (4 projects), and Laos (1 project); and several countries in the region have also started national-level preparations to engage with a future REDD+ mechanism where most projects are replacement of swidden agriculture (slash-and-burn or shifting cultivation) to other systems that potentially reduce emissions and/or increase carbon sequestration. Although the benefits of REDD+ are deemed to be attractive, they may be difficult to achieve as it depends critically on a country or region's particular circumstances. As REDD+ implementation has three phases: readiness, policy reforms, and result-based action (Brockhaus \& Angelsen, 2012), this research will concern with the first phase in terms of REDD+ architecture in Indonesia by particular reference to the national culture of the respective country.

The cultural theory approach is seen to be helpful as framing approach for thinking creatively about available forms of organization and in exploring a variety of what-to-do ideas that surround public services and government (Hood, 1998). National culture can be defined as country's shared practices and values. Values define conceptions of the desirable, and guide the way social actors (e.g. organizational leaders, policy makers, individual persons) select actions, and evaluate people and events (Schwartz, 1992). They represent the implicitly or explicitly shared abstract ideas about what is good, right, and desirable in a society.

Despite that most empirical research finds the causal link between national culture and environmental performance for countries, the effect of national culture on firms' environmental proactivity has not been explored so far (Calza, et.al, 2016) and scholars have started to consider the influence of national culture on environmental proactivity (Paulraj, 2009; Bansal and Roth, 2000). Therefore, based on these considerations, cultural values should have a direct influence on environmental proactivity like REDD+ program.

The main purpose of the paper is to analyze how national culture measured by cultural dimensions provided by Hofstede (2007) act as a stimulating driver for a firm's proactive environmental strategy coined in 'REDD+' (Reducing Emissions from Deforestation and forest Degradation) project as carbon economy within Indonesian setting. 


\section{Literature RevieW AND Propositions}

\section{A National Cultural Ecology}

Hofstede's (1980) seminal work on national culture noted several dimensions along which national cultures differ: individualism vs collectivism, power distance (PD), uncertainty avoidance (UA), masculinity versus femininity, and time orientation. Hofstede (2007) maintained that these dimensions reflect 'basic problems that any society has to cope with but solutions differ'. The national culture model (Hofstede, 2001; Hofstede Hofstede \& Minkov, 2010) has been widely applied in previous academic research in different fields such as accounting, management, economics and sociology.

Power distance measures "the extent to which a community accepts and endorses authority, power differences, and status privileges" (House et al., 2004). High PD nations are more likely to have employees who obey the orders of their superiors without question. Malaysian public institutions are often characterized as highly centralized, control-oriented public sectors that are accountable to superiors (Alam Siddiquee, N. 2010). Poor governance practices at the lower levels are the consequence of poor practices at the higher levels. In addition, organizations that are high in PD have less employee participation in decision making. Javidan, et.al (2006) contended that teambuilding and participative decision-making are not effective in high PD countries and cultures because employees from the different levels are not comfortable interacting face to face in a group due to the top-down hierarchical structure. This is against the basic principles of REDD+ which is to encourage decisionmaking partnerships, networks, and interchange among stakeholders (Corbera, E., \& Schroeder, H. 2011). Given that high levels of power distance are associated with authoritarianism, polarization, and inequalities (Cohen et al., 1996), we conclude that in high power distance societies, managers are less aware of others' needs and of environmental matters as well. In line with Zollo and Ringov (2007) discovered a negative relationship between power distance and social environmental initiatives, REDD+ environmental initiatives, is more likely to have success in such low PD cultures. On the basis of the above discussion, it is proposed that a country with a higher PD is less likely to implement REDD+ successfully.

The first proposition of this study's formulation is therefore presented as follows:

\section{Proposition 1: Low Power Distance is Preferable to Implement Carbon Economy Successfully}

Uncertainty avoidance measures "the extent to which a society, organization, or group relies on social norms, rules, and procedures to alleviate the unpredictability of future events" (House et al., 2004).

In high uncertainty avoidance societies, people tend to be more anxious (Hofstede, 2001; House et al., 2004), take moderate, carefully calculated risks, rely on formalized policies and procedures and show strong resistance to change. They create rules and formalize policies and procedures to ensure standardization and conformity that foster continuity. Schneider and de Meyer (1991) noted that people in high UA cultures tend to respond more forcefully to environmental uncertainty, have a greater concern for stability and security, and desire instruments to control their lives. Parboteeah et al. (2012), indeed, explain that in high uncertainty avoidance societies, individuals will be willing to put in place systems and procedures to ensure the sustainability of the environment by reducing or removing any uncertainty that might have a negative impact on the environment. In so doing, people are likely to remove anxiety that might be associated with uncertain environmental conditions. In contrast, in low uncertainty avoidance societies like in Indonesia, people may not be concerned about uncertainties in the environment since they are more comfortable with ambiguity and uncertainty. People in low UA societes favor well-defined rules and regulations that reduce innovation by public officials. This militates against the reforms initiated under REDD+ that aim to broaden managerial discretion and innovation in the interests of achieving substantive results (Sunderlin, et.al, 2015). Consequently, we develop the following proposition:

\section{Proposition 2: High Uncertainty Avoidance is Preferable to Implement Carbon Economy Successfully}

Individualism characterizes a society in which the ties between individuals are loose, and everyone is expected to look after himself or herself and his or her immediate family members only. Ho et al. (2012) consider that individualistic communities tend to appreciate freedom and independence and usually prioritize personal interests than the common well-being. Collectivism characterizes a society 
in which people from birth onward are integrated into strong, cohesive in-groups, which, throughout one's lifetime, continue to protect him or her in exchange for unquestioning loyalty. Therefore, individualism refers to the importance of the individuals in the society, and personal rights tend to have much influence. In contrast, collectivist societies would exhibit close ties between individuals, extended families, and collectives where everyone takes responsibility for fellow members of their group (Peng \& Lin, 2009). According to Husted (2005) and Scholtens \& Dam (2007), a society that fosters collectivism tends to have its members integrated in groups early in their lives. Thus, the focus is more on the group than on the individual, the predominant values include cohesion and consensus, thus reducing initiatives for individuals. In this way, Akaah (1990) revealed that workers of individualistic countries were less ethic than those pertaining to collectivist countries. As such, one would expect collectivist societies to emphasize more of a concern about the impact of business on society (Ho et al., 2012). Similarly, Blodgett, Lu, Rose, and Vitell (2001) addressed that collectivist societies are likely to be more sensitive to the stakeholders' interests. This was also confirmed by García-Sánchez, Cuadrado-Ballesteros, and Frias-Aceituno (2016), also revealing that companies from collectivistic countries tend to have greater incentives to disclose social and environmental information to their stakeholders, to favor their decision-making processes. Based on the previous reasoning, the following proposition is proposed:

\section{Proposition 3: Collective Societies is Preferable to Implement Carbon Economy Successfully}

Cultures with a high degree of masculinity often represent a preference in society for achievement, heroism, assertiveness, and material rewards for success, while feminine cultures stand for a preference for cooperation, modesty, caring for the weak, and quality of life (Hofstede, 2007). People from assertive societies are expected to "manage their own affairs" (Chui and Kwok, 2009), suggesting that they may pay less attention to initiatives beyond their own interests, such as environmental protection. Husted, (2005); Orij (2010) and Park et al. (2007) argued that the higher the degree of femininity of a given culture, the higher the degree of sustainability, environmental management, and commitment to sustainable development. These findings were confirmed in later research developed by Peng and Lin (2009). Zollo and Ringov (2007) find a positive relationship between gender egalitarianism and environmental performance. Also Tobey \&Yasanthi Perera (2012) find a positive effect of gender egalitarianism on CSR. The positive effect of gender egalitarianism is coherent with the idea that gender egalitarianism is evidence of femininity, that is the inclination to care about the environment, the quality of life, and future generations (Power et al., 2015; Calvelli and Cannavale, 2013). Based on previous discussed research, the following proposition is proposed:

\section{Proposition 4: Feminine Societies is Preferable to Implement Carbon Economy Successfully}

Normativism/Pragmatism is the fifth dimension which differentiates national cultures in this sense, Hofstede (2001) indicates that normative societies prefer to maintain time-honored traditions mean while viewing societal change with suspicion. On the contrary, pragmatic societies encourage thrift and efforts in modern education as a way to prepare for the future (Hofstede \& Minkov, 2010). Pragmatic cultures welcome values such as persistence, saving money, honesty, adaptation, ability, and selfsufficiency and discipline, and companies operating under this scheme mostly focus on accountability principles and on achieving long-term financial and non-financial objectives (Hofstede \& Minkov, 2010). On the contrary, in short-term oriented or normative cultures, main work values are freedom, rights, achievement, and thinking for oneself. In fact, Hackert et.al, (2012) revealed that investments in pollution prevention, investments in recycling, and waste reduction were mainly done by companies operating in pragmatic cultures. This consideration is in line with the idea that pragmatic cultures are more committed to environmental preservation and related sustainability issues. Based on these premises, the following proposition is proposed:

\section{Proposition 5: Pragmatic Societies Preferable to Implement Carbon Economy Successfully}

\section{Data Analysis}

Indonesia scores high on Power Distance (score 78 out of 100 ) which means that the following characterizes the Indonesian style: Being dependent on hierarchy, unequal rights between power holders and non power holders, superiors in-accessible, leaders are directive, management controls and delegates. Power is centralized and managers count on the obedience of their team members. Employees expect to be told what to do and when. Control is expected and managers are respected for their position. Communication is indirect and negative feedback hidden. High Power Distance also 
means that Indonesian co-workers would expect to be clearly directed by the boss or manager - it is the classic Guru-Student kind of dynamic that applies to Indonesia. Westerners may be considerably surprised with the visible, socially acceptable, wide and unequal disparity between the rich and poor.

Indonesia scores (48) on uncertainty avoidance and thus has a low preference for avoiding uncertainty. This means that there is a strong preference in Indonesia toward the Javanese culture of separation of internal self from external self. When a person is upset, it is habitual for the Indonesian not to show negative emotion or anger externally. They will keep smiling and be polite, no matter how angry they are inside. This also means that maintaining work place and relationship harmony is very important in Indonesia, and no one wishes to be the transmitter of bad or negative news or feedback. Another aspect of this dimension can be seen in Conflict resolution. Direct Communication as a method of conflict resolution is often seen to be a threatening situation and one that the Indonesian is uncomfortable in. A tried and tested, successful method of conflict diffusion or resolution is to take the more familiar route of using a third party intermediary, which has many benefits. It permits the exchange of views without loss of face as well as since one of the main manifestations of Indonesia's Uncertainty Avoidance is to maintain the appearance of harmony in the workplace; an intermediary removes the uncertainty associated with a confrontation. Perhaps one very key phrase in Indonesia that describes how this works is "Asal Bapak Senang" (Keep the Boss Happy).

Indonesia, with a low score of (14) is a Collectivist society. This means there is a high preference for a strongly defined social framework in which individuals are expected to conform to the ideals of the society and the in-groups to which they belong. One place this is visible clearly is in the aspect of the Family in the role of relationships. For example, In Indonesia, if one wishes to marry, it is important to meet a woman's family because the family is so important to her. If a man wants to be taken seriously by a woman, he has to visit the latter's family and introduce himself formally to the parents of the girl. It is inappropriate to court a woman and formalize the relationship without informing the parents of the girl first. Another example of collectivist culture of Indonesia is in the equation between child and parent Indonesian children are committed to their parents, as are the parents committed to them all their growing lives. Their desire is to make their parents' life easier. There is a desire to take care of parents and give them support in their old age. There is an Asian saying that is accepted in Indonesia, "You can get another wife or husband but not another mother or father". This family loyalty is also apparent in the fact that Indonesian families keep elders (such as grandparents) at home instead of sending them to any institution. In Individualist societies the focus is on the nuclear family only.

Indonesia scores (46) thus considered low Masculine. While not entirely like most North European countries who are very low in Masculinity and thus considered Feminine, Indonesia is less Masculine than some other Asian countries like Japan, China and India. In Indonesia status and visible symbols of success are important but it is not always material gain that brings motivation. Often it is the position that a person holds which is more important to them because of an Indonesian concept called "gengsi" - loosely translated to be, "outward appearances". It is important that the "gengsi" be strongly maintained thereby projecting a different outward appearance aimed at impressing and creating the aura of status.

Normatism/pragmatism describes how every society has to maintain some links with its own past while dealing with the challenges of the present and future, and societies prioritise these two existential goals differently. Normative societies. which score low on this dimension, for example, prefer to maintain time-honoured traditions and norms while viewing societal change with suspicion. Those with a culture which scores high, on the other hand, take a more pragmatic approach: they encourage thrift and efforts in modern education as a way to prepare for the future.

Indonesia's high score of 62 indicates that it has a pragmatic culture. In societies with a pragmatic orientation, people believe that truth depends very much on situation, context and time. They show an ability to adapt traditions easily to changed conditions, a strong propensity to save and invest, thriftiness, and perseverance in achieving results.

\section{Conclusion}

Drawing on frameworks of Hofstede's national culture, the cultural ecology presents some problem for carbon economy implementation in Indonesia. The five cultural dimensions reveals that Indonesia scores high in PD, medium in UA, high in collectivism, feminine society and pragmatic societies. The 
rhetoric of carbon economy as expressed in REDD+, cannot be applied universally in the presence of cross-cultural differences. By using Turner's (2002) metaphor, three types of diners are used to illustrate the readiness of implementing REDD+ in Southeast Asia Countries. Enthusiastic diners are represented by Indonesia (44 projects), cautious diners are represented by Vietnam ( 7 projects) and Philippines (4 projects) and diners who are unfamiliar with the menu are represented by Malaysia, Thailand, Laos (1 project each). The enthusiastic diners have bureaucracies that are capable of learning and adapting. The cautious diners demonstrate some degree of decentralization and privatization, but with only minimal changes within the centralized state. The unfamiliar diners have yet to build capacity and systemic processes to initiate and sustain reform in forest sustainable management initiatives. Since Indonesia is placed in entusiastic diners Empirical insights into REDD+ attempts from national culture insight most clearly indicate that Indonesians are not all fitted into this framework mainly in power distance dimension. However, Indonesia that has become a leader in international efforts to reduce emissions from deforestation and forest degradation in developing countries in Sutheast Asia proving that the country has been successfully exploited those components of such models that are relevant to its own societal contexts and people's need.

\section{REFERENCES}

Bansal, P., \& Roth, K. (2000). Why companies go green: A model of ecological responsiveness. Academy of management journal, 43(4), 717-736.

Blodgett, J. G., Lu, L. C., Rose, G. M., \& Vitell, S. J. (2001). Ethical sensitivity to stakeholder interests: A cross-cultural comparison. Journal of the Academy of Marketing Science, 29(2), 190202.

Brockhaus, M., \& Angelsen, A. (2012). Seeing REDD+ through 4Is: a political economy framework. Analysing REDD+: challenges and choices. Center for International Forestry Research, Bogor, Indonesia, 15-30.

Calvelli, A., \& Cannavale, C. (2013). Competenze culturali e internazionalizzazione delle imprese. G Giappichelli Editore.

Calza, F., Calza, F., Cannavale, C., Cannavale, C., Tutore, I., \& Tutore, I. (2016). The important effects of national culture on the environmental proactivity of firms. Journal of Management Development, 35(8), 1011-1030.

Cohen, J. R., Pant, L. W., \& Sharp, D. J. (1996). A methodological note on cross-cultural accounting ethics research. The International Journal of Accounting, 31(1), 55-66.

Corbera, E., \& Schroeder, H. (2011). Governing and implementing REDD+. Environmental science \& policy, 14(2), 89-99.

Chui, A. C., \& Kwok, C. C. (2009). Cultural practices and life insurance consumption: An international analysis using GLOBE scores. Journal of Multinational Financial Management, 19(4), 273-290.

Garcia-Sanchez, I. M., Cuadrado-Ballesteros, B., \& Frias-Aceituno, J. V. (2016). Impact of the Institutional Macro Context on the Voluntary Disclosure of CSR Information. Long Range Planning, 49(1), 15-35.

Hackert, A. M., Krumwiede, D., Tokle, J., \& Vokurka, R. J. (2012). Global corporate social responsibility practices and cultural dimensions. SAM Advanced Management Journal, 77(4), 33.

Hood, C. (2000).The art of the state: Culture, rhetoric, and public management. Oxford University Press.

Ho, F. N., Wang, H. M. D., \& Vitell, S. J. (2012). A global analysis of corporate social performance: The effects of cultural and geographic environments. Journal of business ethics, 107(4),423-433.

Hofstede, G. (1980). Culture and organizations. International Studies of Management \& Organization, 10(4), 15-41.

Hofstede, G. H., \& Hofstede, G. (2001). Culture's consequences: Comparing values, behaviors, institutions and organizations across nations. Sage.

Hofstede, G. (2007). Asian management in the 21 st century. Asia pacific journal of management, 24(4), 411-420.

Hofstede, G., \& Minkov, M. (2010). Long-versus short-term orientation: new perspectives. Asia Pacific Business Review, 16(4), 493-504. 
House, R. J., Hanges, P. J., Javidan, M., Dorfman, P. W., \& Gupta, V. (Eds.). (2004). Culture, leadership, and organizations: The GLOBE study of 62 societies. Sage publications.

Husted, B. W. (2005). Culture and ecology: A cross-national study of the determinants of environmental sustainability. MIR: Management International Review, 349-371.

Javidan, M., House, R. J., Dorfman, P. W., Hanges, P. J., \& De Luque, M. S. (2006). Conceptualizing and measuring cultures and their consequences: A comparative review of GLOBE's and Hofstede's approaches. Journal of international business studies, 37(6), 897-914.

Karsenty, A., \& Ongolo, S. (2011). Can'fragile states' decide to reduce their 410 deforestation? The inappropriate use of the theory of incentives with respect to the REDD mechanism. Forest Policy and Economics, In Press, Corrected Proof, Available online, 16.

Orij, R. (2010). Corporate social disclosures in the context of national cultures and stakeholder theory. Accounting, Auditing \& Accountability Journal, 23(7), 868-889.

Parboteeah, K. P., Addae, H. M., \& Cullen, J. B. (2012). Propensity to support sustainability initiatives: A cross-national model. Journal of business ethics, 105(3), 403-413.

Park, H., Russell, C., \& Lee, J. (2007). National culture and environmental sustainability: A crossnational analysis. Journal of Economics and Finance, 31(1), 104-121.

Paulraj, A. (2009). Environmental motivations: a classification scheme and its impact on environmental strategies and practices. Business Strategy and the Environment, 18(7), 453-468.

Peng, Y. S., \& Lin, S. S. (2009). National culture, economic development, population growth and environmental performance: The mediating role of education. Journal of Business Ethics, 90(2), 203-219.

Power, D., Klassen, R., Kull, T. J., \& Simpson, D. (2015). Competitive Goals and Plant I nvestment in Environment and Safety Practices: Moderating Effect of National Culture. Decision Sciences, 46(1), 63-100.

Ringov, D., \& Zollo, M. (2007). The impact of national culture on corporate social performance. Corporate Governance: The international journal of business in society, 7(4), 476- 485.

Schneider, S. C., \& De Meyer, A. (1991). Interpreting and responding to strategic issues: The impact of national culture. Strategic management journal, 12(4), 307-320.

Scholtens, B., \& Dam, L. (2007). Cultural values and international differences in business ethics. Journal of Business Ethics, 75(3), 273-284.

Schwartz, S. H. (1992). Universals in the content and structure of values: Theoretical advances and empirical tests in 20 countries. Advances in experimental social psychology, 25, 1- 65.

Sunderlin, W. D., Sills, E. O., Duchelle, A. E., Ekaputri, A. D., Kweka, D., Toniolo, M. A., ... \& Enright, A. (2015). REDD+ at a critical juncture: assessing the limits of polycentric governance for achieving climate change mitigation. International Forestry Review, 17(4), 400-413.

Tobey Sr, D. H., \& Yasanthi Perera, B. (2012). Corporate social responsibility initiatives: a stakeholder model for aligning competing values in West Africa. African Journal of Economic and Management Studies, 3(1), 95-115.

Turner, M. (2002). Choosing items from the menu: New public management in Southeast Asia. International Journal of Public Administration, 25(12), 1493-1512. 